
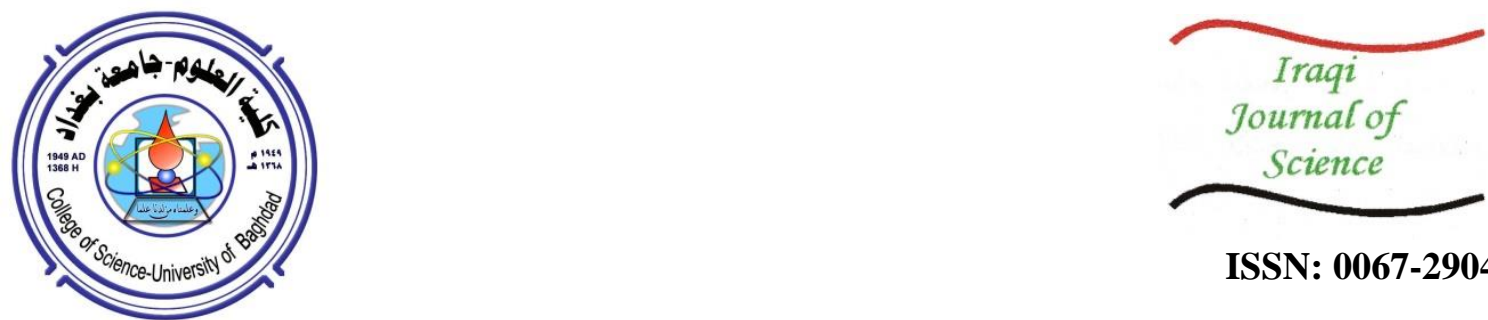

ISSN: 0067-2904

\title{
Detection of Some Immunological Parameters in Psoriatic Iraqi Female Patients
}

\author{
Rehab Morad Khazem*, Shaima R. Ibraheem \\ Department of Biotechnology, College of Science, University of Baghdad, Baghdad, Iraq
}

Received: 9/1/2020

Accepted: $15 / 3 / 2020$

\begin{abstract}
Psoriasis is a common, chronic, immune-mediated skin disease with systemic pro-inflammatory activation. This study was designed to estimate the level of two cytokines, Interleukin-36 (IL-36) and Interleukin-10 (IL-10), in psoriasis female patients. The study was accomplished on 50 Iraqi patients with psoriasis who were referred to the consulting clinic at Al-Yarmouk Teaching Hospital during the period from November 2018 to March 2019. These patients were diagnosed under the supervision of dermatologists. For the purpose of comparison, the study included 30 healthy women as a healthy control group. The serum levels of cytokines were measured using the enzyme-linked immunosorbent technique (ELISA).The results of this study showed that the mean age of the female patients was $35.9 \pm 1.85$ years, whereas the age of the patients with a severity of higher than 30\% ranged 15-25 years. Most of the patients were married, in an average living condition, and nonsmokers, and their menstrual cycle was continuous. It was also found that $28 \%$ of the psoriatic patients had other chronic diseases. The study showed statistically significant differences $(p<0.05)$ in the mean level of IL-36 between the patients and healthy control group, whereas there was no statistical difference in the mean level of IL-10. In conclusion, the decrease in the level of IL-36 in the patients might be related to the increase in the severity of the disease.
\end{abstract}

Keywords: Psoriasis, Interleukin-36, Interleukin-10.

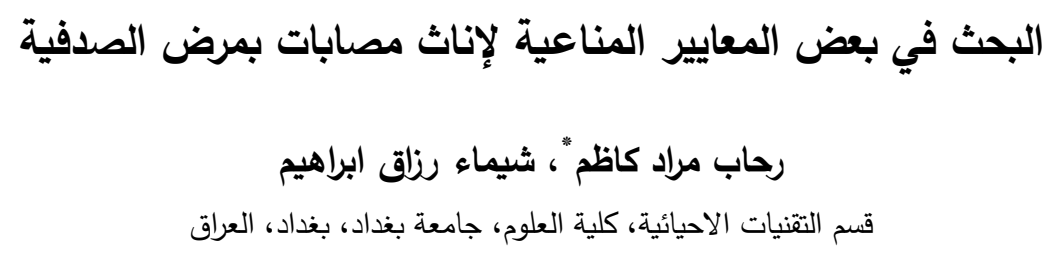

\footnotetext{
الخلاصه

الصدفية هي مرض مناعي جلدي شائع مزمن يتميز بنشاط النظام الالتهابي. تم تصميم هذه الدراسة لتتدير

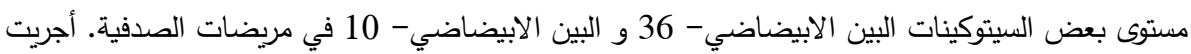
هذه الدراسة على 50 مريضة عراقية مصابة بالصدفية تم إحالتهن إلى العيادة الاستشارية في مستشفى الإنى

*Email: aliai8@yahoo.com 


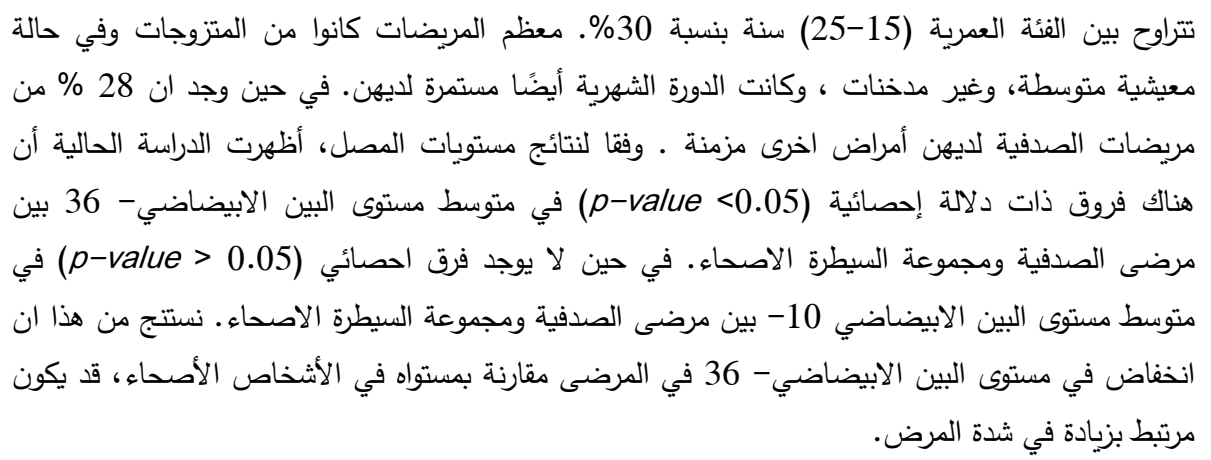

\section{Introduction}

Psoriasis is a chronic inflammatory (immune-mediated) skin disease, affecting approximately 2-3\% of the world's population. While it is more common in Caucasians, it can affect any race and can occur at any age, being recognized by a change in the proliferation and differentiation of keratinocytes $[1,2]$. Psoriasis is also characterized by the inflammation and scaling of the skin [3]. The disease is caused by the association of distorted keratinocytes and improper innate and adaptive immune responses. The causes of the defect in the keratinocytes are not known, but the evidence indicated that genetic, environmental, and immunological factors play important roles in the development of psoriasis $[3,4]$.

The dysregulated interactions of the innate and adaptive immune responses that are associated with psoriasis affect the epithelial and connective tissues of the skin [5]. Psoriasis is also characterized by an increased activation of T lymphocytes and systemic and local overexpression of pro-inflammatory cytokines such as interleukin 2 (IL-2), gamma interferon (IFN- $\gamma$ ), interleukin-6 (IL-6) and tumor necrosis factor-alpha (TNF- $\alpha)[6]$.

Interleukin-36 (IL-36) is a member of the IL-1 superfamily, which has four existing isoforms [7], assigned as IL-36 $\alpha$, IL-36 $\beta$, IL-36 $\gamma$, and IL-36 receptor antagonist (Ra) [8]. IL-36 is increasingly associated with inflammatory diseases, including various inflammatory and infectious skin disorders [9]. Among these, psoriasis is the most prominent skin disease associated with IL-36 [10].

Interleukin-10 (IL-10) is a cytokine with anti-inflammatory properties that has a central role in infections by limiting the immune response to pathogens and thereby preventing damage to the host [11]. It also has a crucial role in preventing inflammatory and autoimmune pathologies [12]. Longterm application of IL-10 in psoriatic patients showed that it had moderate anti-psoriatic effects, was well tolerated, decreased the incidence of relapse, and prolonged the disease-free interval [13]. The pathogenesis of psoriasis and other autoimmune diseases involves a genetic background and environmental triggers. Like other autoimmune diseases, psoriasis was shown to have a strong genetic component, with a concordance rate in identical twins of 40-70\% $[1,3]$.

This study aimed to evaluate the levels of both IL-10 and IL-36 that might be associated with the exacerbation of psoriasis in Iraqi patients.

\section{Materials and Methods \\ Subjects}

A sample was collected from patients suffering from severe or moderate psoriasis. The study included 50 Iraqi female patients in Al-Yarmouk educational hospital during the period from November 2018 to March 2019, while another group consisted of 30 healthy females as a control. The patients were treated with classical psoriasis treatments, such as biological (pills or injections) and chemical therapy. The complete history of illness in the patients was recorded in a questionnaire sheet.

\section{Blood sampling}

Five milliliters of blood were collected by vein puncture from all patients and control subjects. The blood was allowed to coagulate for 10-20 minutes at room temperature and centrifuged at 2000-3000 rpm for 15 minutes. The collected serum was distributed in three to four Eppendorf tubes and kept at a temperature of $-20{ }^{\circ} \mathrm{C}$ to be used later.

\section{Measurements of immunological and biochemical parameters}

Serum levels of Cytokines (IL-36 and IL-10) were measured using the ELISA kit from Elabscience, USA, following the steps in the manufacturer's protocol. 


\section{Statistical analysis}

Comparisons of qualitative data were carried out using Chi-square test $\left(\chi^{2}\right)$. While quantitative data were handled using ANOVA test. Statistical analysis was performed using the statistical package SPSS for Windows (version 23, SPSS Inc., Chicago, IL, USA). A probability value of less than 0.05) was adopted to indicate statistical significance for each test [14].

\section{Results and Discussion}

\section{Description of the Studied Samples}

The pictures in Figure -1 represent various pathological cases of psoriasis patients included in the study and note the differences in pathological severity. Demographical distribution of the studied groups according to different parameters (age, social status, living situation, being in the period, smoking, kinds of other chronic diseases, and the treatment used) is summarized in Table-1. The results clarified that the age ranged between 15-65 years and the mean age was 35.9 \pm 1.85 years. Most of psoriatic patients and control subjects were within the age group of 15-25 year (30\% vs. $50 \%$,), while the lowest percentages were within the age group of 56-65 year. Also, it was found that about 54 $\%$ of psoriatic patients are married, $90 \%$ with an average living situation, $64 \%$ with continuous period, $98 \%$ none-smokers, $72 \%$ have no chronic disease, and $76 \%$ used treatments for other chronic diseases.

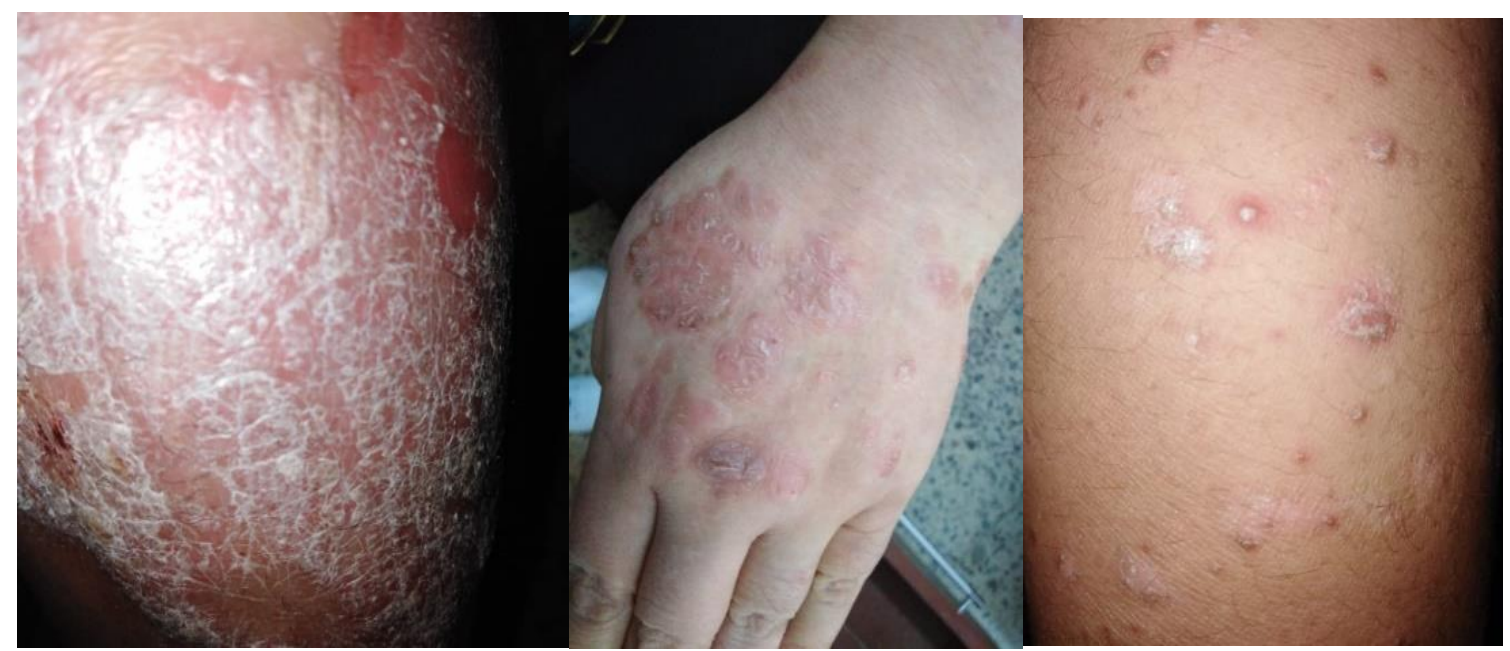

Figure 1- Images of various severity levels of psoriasis from different patients in the present study.

Many previous studies investigated the mean age in patients with psoriasis. One local study [15] and another one conducted in another country [16] showed similar mean ages of psoriasis patients as those found in the present study, being mostly within the second decade. Also, a study in Turkey reported that the mean age was 37.8 years [17], whereas 34.5 years was the mean age recorded in Northern India [18]. Psoriasis can occur at any age, while its prevalence increases with age and peaks between the second and third decades, usually because of wars in the past twenty years that caused major pollution events and, consequently, the appearance of several diseases [19]. Geographic location influences the likelihood of having psoriasis; disease prevalence tends to increase with increasing distance from the equator. Moreover, a systematic worldwide review found that the prevalence of psoriasis ranged from 0.5-11.4\% in adults and 0-1.4\% in children. These differences are the result of differences in the region, the randomness of samples, and average age of the people in different countries [2]. 
Table 1- The percentage distribution of the studied groups according to different categories.

\begin{tabular}{|c|c|c|c|c|c|c|c|}
\hline \multirow[b]{2}{*}{ Variables } & \multirow[b]{2}{*}{ Status } & \multicolumn{3}{|c|}{ Patient $(\mathrm{N}=50)$} & \multicolumn{3}{|c|}{ Control $(\mathrm{N}=\mathbf{3 0})$} \\
\hline & & $\begin{array}{c}\text { Frequenc } \\
y\end{array}$ & $\begin{array}{c}\text { mean } \pm \\
\text { SEM }\end{array}$ & $\begin{array}{c}\text { Percentage } \\
\%\end{array}$ & $\begin{array}{c}\text { Frequenc } \\
\mathrm{y}\end{array}$ & $\begin{array}{c}\text { mean } \pm \\
\text { SEM }\end{array}$ & $\begin{array}{c}\text { Percentag } \\
\mathrm{e} \\
\%\end{array}$ \\
\hline \multirow{5}{*}{ Age } & $15-25$ year & 15 & \multirow{5}{*}{$\begin{array}{c}35.9 \\
\pm \\
1.85\end{array}$} & 30 & 15 & \multirow{5}{*}{$\begin{array}{c}28.7 \\
\pm \\
1.73\end{array}$} & 50 \\
\hline & 26-35 year & 10 & & 20 & 9 & & 30 \\
\hline & $36-45$ year & 13 & & 26 & 4 & & 13.3 \\
\hline & 46-55 year & 10 & & 20 & 2 & & 6.7 \\
\hline & 56-65 year & 2 & & 4 & 0 & & 0 \\
\hline \multirow{4}{*}{$\begin{array}{l}\text { Social } \\
\text { status }\end{array}$} & Married & \multicolumn{2}{|c|}{27} & 54 & \multicolumn{2}{|c|}{16} & 53.3 \\
\hline & Single & \multicolumn{2}{|c|}{19} & 38 & \multicolumn{2}{|c|}{14} & 46.7 \\
\hline & Divorced & \multicolumn{2}{|l|}{3} & 6 & \multicolumn{2}{|l|}{0} & 0 \\
\hline & Widow & \multicolumn{2}{|l|}{1} & 2 & \multicolumn{2}{|l|}{0} & 0 \\
\hline \multirow{3}{*}{$\begin{array}{l}\text { Living } \\
\text { situation }\end{array}$} & Good & \multicolumn{2}{|l|}{3} & 6 & \multicolumn{2}{|l|}{7} & 23.4 \\
\hline & Average & \multicolumn{2}{|c|}{45} & 90 & \multicolumn{2}{|c|}{19} & 63.3 \\
\hline & weak & \multicolumn{2}{|l|}{2} & 4 & \multicolumn{2}{|l|}{4} & 13.3 \\
\hline \multirow{3}{*}{$\begin{array}{c}\text { The } \\
\text { Menstrual }\end{array}$} & Continuous & \multicolumn{2}{|c|}{32} & 64 & \multicolumn{2}{|c|}{22} & 73.3 \\
\hline & During period & \multicolumn{2}{|l|}{5} & 10 & \multicolumn{2}{|l|}{7} & 23.4 \\
\hline & Stopped & \multicolumn{2}{|c|}{13} & 26 & \multicolumn{2}{|l|}{1} & 3.3 \\
\hline \multirow{2}{*}{ Smoke } & Smoker & \multicolumn{2}{|l|}{1} & 2 & \multicolumn{2}{|l|}{3} & 10 \\
\hline & None & \multicolumn{2}{|c|}{49} & 98 & 27 & & 90 \\
\hline Kind of & Found & 14 & & 28 & 8 & & 26.7 \\
\hline disease & None & 36 & & 72 & 22 & & 73.3 \\
\hline The used & Used & 12 & & 24 & 8 & & 26.7 \\
\hline $\begin{array}{l}\text { of chronic } \\
\text { disease }\end{array}$ & None & 38 & & 76 & 22 & & 73.3 \\
\hline
\end{tabular}

*SEM: Std. error of Mean.

Previous studies showed that $46.9 \%$ [20] and 55\% [21] of psoriatic patients were females. Our results showed an interesting observation that higher (social class) living situation in psoriasis patients was very low compare with below social class, and represented a small low risk of psoriasis. Social class determines many lifestyle parameters that could be risk factors for psoriasis; these factors include smoking, stress, jobs, exposure to sunlight...etc. [20]. Disease flares are known to occur in stressful life situations and certain literature links psoriasis activity to stress from major life events [22]. 
Table 2- Values of different variables of psoriatic patients.

\begin{tabular}{|c|c|c|c|c|c|}
\hline Group & Variables & Status & Frequency & $\begin{array}{c}\text { Mean } \pm \\
\text { SEM }\end{array}$ & Percentage $\%$ \\
\hline \multirow{5}{*}{$\mathbf{A}$} & \multirow{5}{*}{$\begin{array}{c}\text { Period of } \\
\text { disease }\end{array}$} & $<1$ year & 3 & \multirow{5}{*}{$8.14 \pm 1.05$} & 6 \\
\hline & & $1-10$ year & 32 & & 64 \\
\hline & & 11-20 year & 10 & & 20 \\
\hline & & 21-29 year & 3 & & 6 \\
\hline & & None & 2 & & 4 \\
\hline \multirow{6}{*}{ B } & \multirow{6}{*}{$\begin{array}{l}\text { Period of } \\
\text { treatments }\end{array}$} & $<1$ year & 17 & \multirow{6}{*}{$1.87 \pm 0.47$} & 34 \\
\hline & & 1-4 year & 17 & & 34 \\
\hline & & 5-8 year & 6 & & 12 \\
\hline & & $>8$ year & 1 & & 2 \\
\hline & & Continuous & 8 & & 16 \\
\hline & & Intermittent & 1 & & 2 \\
\hline \multirow{4}{*}{$\mathbf{C}$} & \multirow{4}{*}{$\begin{array}{l}\text { The causes of } \\
\text { disease }\end{array}$} & After birth & \multirow{2}{*}{\multicolumn{2}{|c|}{$\begin{array}{c}5 \\
16\end{array}$}} & 10 \\
\hline & & Hereditary & & & 32 \\
\hline & & Psychological state & \multicolumn{2}{|c|}{28} & 56 \\
\hline & & trauma & \multicolumn{2}{|c|}{1} & 2 \\
\hline \multirow{5}{*}{ D } & \multirow{5}{*}{$\begin{array}{l}\text { The kind of } \\
\text { treatment }\end{array}$} & Biological injection & \multicolumn{2}{|c|}{9} & 18 \\
\hline & & $\begin{array}{l}\text { Biological injection } \\
\text { and Traditional drug }\end{array}$ & \multicolumn{2}{|c|}{1} & 2 \\
\hline & & Biological pills & \multicolumn{2}{|c|}{31} & 62 \\
\hline & & Chemical pills & \multicolumn{2}{|c|}{1} & 2 \\
\hline & & Traditional drug & \multicolumn{2}{|c|}{8} & 16 \\
\hline \multirow{7}{*}{\multicolumn{2}{|c|}{ Chi-square $\left(X^{2}\right)$ test }} & Groups & $X^{2}$ & p-value & Sig. \\
\hline & & $A$ vas B & 42.872 & $0.002^{*}$ & Significant \\
\hline & & $A$ vas $C$ & 9.992 & 0.617 & None-Significant \\
\hline & & $A$ vas D & 5.263 & 0.994 & None-Significant \\
\hline & & $B$ vas $C$ & 10.069 & 0.815 & None-Significant \\
\hline & & B vas D & 16.653 & 0.675 & None-Significant \\
\hline & & C vas D & 12.39 & 0.415 & None-Significant \\
\hline
\end{tabular}

*SEM: Std. error of Mean.

The pathological characteristics of the 50 patients with psoriasis (period of the disease, the period of treatments, the causes of disease, and the kind of treatment) are summarized in Table- 2 . The results clarified that the most patients $(64 \%)$ had a period of 1-10 years since the first appearance of the disease, while the mean period was $8.14 \pm 1.05$ years. The period of treatment was mostly lower than 1 year, with a range of $1-4$ years in $34 \%$ of the patients, while the mean period of $1.87 \pm 0.47$. Most of the patients (62) used biological pills, mainly cortisone, for treatment. The psychological state was the most affecting parameter (56\%) for causing the disease. Also, $70 \%$ of the patients had the entire body infected by psoriasis. In addition, statically significant differences, as tested by Chi-square $\left(X^{2}\right)$ test, were only recorded in the parameters of the period of the appearance of the disease and the period of treatments.

The defect in keratinocytes associated with psoriasis is caused by several factors including environmental, genetic, and immunologic. The environmental factors break the body balance to affect the onset and development of psoriasis. Other factors like psychological stress are widely believed to play a role, but evidence is controversial on whether the effects are on triggering or exacerbating the disease [4]. Also, family history (heredity) was found in about 30\% of the patients, because of continuous exposure of human body cells to harmful agents, most of which are of oxidative kind, that have the ability to cause deoxyribonucleic acid (DNA) damage [23, 24]. Significant progress in understanding the pathogenesis and treatment of psoriasis has been made in the last several years [25]. 


\section{Serum Levels of Cytokines \\ Serum Level of IL-36}

The psoriatic patients showed a highly significant decrease $(p<0.05)$ in the mean of serum of IL-36 $(64.74 \pm 1.09 \mathrm{pg} / \mathrm{ml})$ compared with its level in the healthy control group $(89.7 \pm 0.62 \mathrm{pg} / \mathrm{ml})$, as shown in Figure-2.

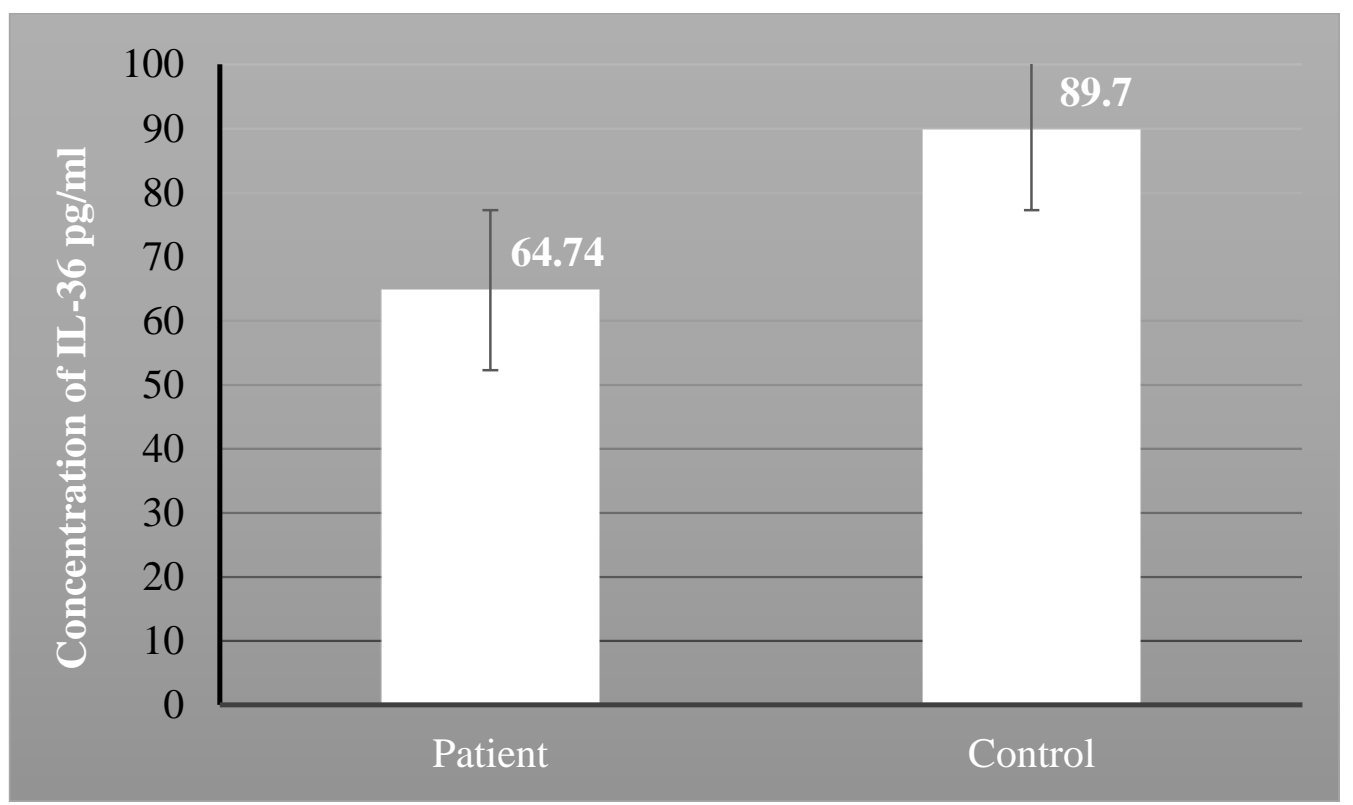

Figure 2- The mean serum level of IL-36 pg/ml in Psoriatic Patients and Healthy Control.

Previous studies showed a high increase of IL-36 level in non-treated psoriatic patients [10, 26, 27]. While, other studies found that serum levels of IL-36 were decreased under treatment [28, 29, 30]. IL36 has important functions in the regulation of immune responses, especially its involvement in many inflammatory conditions. It activates similar intracellular signals as those activated by IL-1 and is involved in the regulation of innate as well as adaptive immune responses [9, 26, 31].

IL-36 cytokines are critical members of the cytokine milieu that drives skin inflammation in this model. IL-36 induces the expression of chemokines by keratinocytes and drives the activation of antigen-presenting cells (APCs) [9, 28, 32]. These observations are consistent with a role for IL-36 in driving psoriatic skin inflammation by attracting neutrophils, myeloid cells, and $\mathrm{T}$ cells into developing psoriatic lesions and altering APC function to potentiate the inflammatory cycle. In early experiments, microgram quantities of recombinant IL-36 ligands were required for inducing keratinocyte responses $[10,28]$.

The potential importance of the IL-36 family in psoriasis was high-lighted by the discovery that the loss-of-function mutations in the IL-36 receptor antagonist gene IL36RN underlie a rare but debilitating form of psoriasis, known as the generalized pustular psoriasis (GPP) [33, 34]. Such mutations leave IL-36 agonist activity unchecked, driving a neutrophilic skin inflammation. Although inhibition of the canonical IL-1 system has not proved to be an effective therapeutic approach in psoriasis [35], targeting the IL-36 system holds promise, particularly in the debilitating conditions of GPP and the closely-related disease palmar-plantar pustulosis (PPP), particularly where mutations in IL36RN have been identified. The involvement of IL-36 may not be restricted entirely to GPP and PPP, as psoriasis tends to occur across a spectrum of phenotypes, and the IL-36 system may play a greater role in the more neutrophilic forms of the disease [36]. Expression of IL-36 has been shown to be restricted to epithelial cells in direct contact with the environment, including the skin [28], which when taken together with the observations above highlight IL-36 as an attractive new therapeutic target for psoriasis [37].

\section{Serum Level of IL-10}

The mean serum level of IL-10 in psoriatic patients showed no significant differences when compared to its level in the healthy control, as shown in Figure-3. IL-10 serum levels in the patients and the healthy control group were $89.89 \pm 1.45$ and $90.67 \pm 0.59 \mathrm{pg} / \mathrm{ml}$, respectively. 


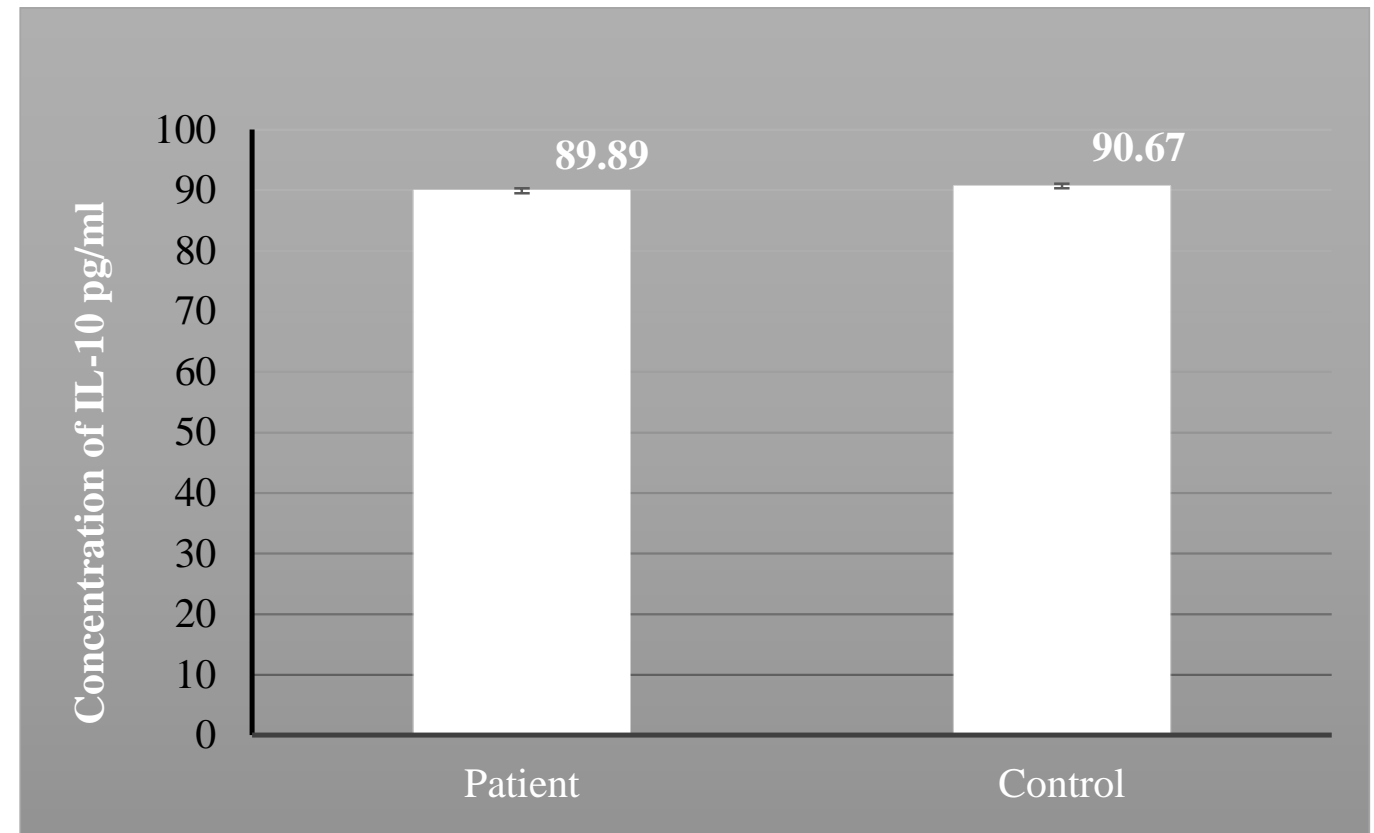

Figure 3- The mean serum level of IL-10 pg/ml in Psoriasis Patients and Healthy Control.

Previous studies reported extremely varied results for the roles of IL-10 in psoriasis. Verghese et al. and Khalaf reported that the mean values of IL-10 concentrations in the patients were nonsignificantly different from those in the control group $[18,15]$. The results above are compatible with those of the current study. While another study by Borska et al. reported that IL-10 concentrations were significantly higher in psoriatic patients, while they were decreased after the treatment. Deeva et al. observed that moderate-to-severe psoriasis patients have a higher level of IL-10 [38, 39]. Few studies demonstrated a significantly decreased serum level of IL-10 in psoriatic patients [40, 41]. Although IL-10 plays an important role in the anti-inflammatory response in psoriasis, the serum levels of IL-10 in patients with psoriasis have been studied only rarely, and the results are contradictory [38].

The significant decrease in mean IL-10 concentration reported by some studies can be explained by a systemic functional deficiency of regulatory $\mathrm{T}$ cells, and the subsequent decrease of serum IL-10 levels that may predispose to psoriasis pathogenesis. Moreover, patients treated with topical treatments and with ultraviolet-B presented lower IL-10 levels than patients treated with systemic drugs [20-18]. Low levels of IL-10 was found in the cutaneous lesions of psoriatic patients; after a progressive disease, high levels of IL-10 can be found in the peripheral blood mononuclear cells [42, 43].

\section{Correlation Coefficient between Interleukins}

The results in this study presented no significant correlation between IL-36 and IL-10 levels in the patients (-0.131) as well as in the control (-0.032) groups, as seen in Table-3.

Table 3 - Correlation Coefficient between Interleukins in this Study

\begin{tabular}{|c|c|c|c|c|}
\hline \multirow{2}{*}{ Interleukins } & \multicolumn{2}{|c|}{ Patient } & \multicolumn{2}{c|}{ Control } \\
\cline { 2 - 5 } & $\begin{array}{c}\text { Correlation } \\
\text { coefficient }\end{array}$ & sig. & $\begin{array}{c}\text { Correlation } \\
\text { coefficient }\end{array}$ & sig. \\
\hline IL-36 and IL-10 & -.131 & $\begin{array}{c}\text { Non- } \\
\text { Significant }\end{array}$ & -.032 & $\begin{array}{c}\text { Non- } \\
\text { Significant }\end{array}$ \\
\hline
\end{tabular}

\section{Association of Serum Levels of IL-36 and IL-10 with Different Varieties of Psoriatic Patients}

The psoriatic patients were divided into different groups according to age, period since appearance of the disease, period of treatment, causes of disease, and kind of treatment. There was a significant association between IL-36 serum levels and age $(p-<0.05)$ but the association with serum levels of IL-10 was non-significant. While the associations of serum levels of IL-36 and IL-10 with all the other groups of patients were insignificant (Table -4$)$. 
Table 4- Values of IL-36 and IL-10 serum levels according to different varieties of Psoriatic Patients.

\begin{tabular}{|c|c|c|c|c|c|}
\hline Variables & Status & $\begin{array}{c}\text { IL-36 } \\
\text { Mean } \pm \text { SEM }\end{array}$ & p value & $\begin{array}{c}\text { IL-10 Mean } \\
\pm \text { SEM }\end{array}$ & $\begin{array}{c}p \\
\text { value }\end{array}$ \\
\hline \multirow{5}{*}{ Age } & $15-25$ year & $69.6 \pm 1.9$ & \multirow{5}{*}{$0.05 *$} & $91.5 \pm 2.6$ & \multirow{5}{*}{0.9} \\
\hline & 26-35 year & $62.9 \pm 1.4$ & & $91.2 \pm 3.6$ & \\
\hline & $36-45$ year & $61.5 \pm 1.6$ & & $88.2 \pm 3.2$ & \\
\hline & 46-55 year & $64 \pm 3.2$ & & $88.6 \pm 2.9$ & \\
\hline & 56-65 year & $62.5 \pm 3.5$ & & $88.5 \pm 7.5$ & \\
\hline \multirow{5}{*}{$\begin{array}{l}\text { Period since } \\
\text { appearance } \\
\text { of disease }\end{array}$} & $<1$ year & $64 \pm 6$ & \multirow{5}{*}{0.45} & $86.7 \pm 3$ & \multirow{5}{*}{0.11} \\
\hline & $1-10$ year & $65.9 \pm 1.3$ & & $88.1 \pm 1.6$ & \\
\hline & 11-20 year & $64.3 \pm 2.9$ & & $97.6 \pm 4.3$ & \\
\hline & 21-29 year & $58 \pm 2$ & & $86 \pm 0.6$ & \\
\hline & None & $60 \pm 1$ & & $91 \pm 2$ & \\
\hline \multirow{6}{*}{$\begin{array}{l}\text { Period of } \\
\text { treatments }\end{array}$} & $<1$ year & $63.7 \pm 2.2$ & \multirow{6}{*}{0.76} & $91.1 \pm 2.5$ & \multirow{6}{*}{0.42} \\
\hline & $1-4$ year & $65 \pm 1.2$ & & $86.8 \pm 2.6$ & \\
\hline & 5-8 year & $68.5 \pm 4.4$ & & $87.1 \pm 2$ & \\
\hline & $>8$ year & $59 \pm 0$ & & $89 \pm 0$ & \\
\hline & Continuous & $65 \pm 2.8$ & & $96 \pm 4.4$ & \\
\hline & Intermittent & $60 \pm 0$ & & $89 \pm 0$ & \\
\hline \multirow{4}{*}{$\begin{array}{c}\text { The causes of } \\
\text { disease }\end{array}$} & After birth & $62.4 \pm 2.9$ & \multirow{4}{*}{0.54} & $85.8 \pm 2$ & \multirow{4}{*}{0.78} \\
\hline & Hereditary & $65.2 \pm 1.9$ & & $90.9 \pm 3.7$ & \\
\hline & Psychological state & $65.2 \pm 1.5$ & & $90.2 \pm 1.5$ & \\
\hline & trauma & $55 \pm 0$ & & $86 \pm 0$ & \\
\hline \multirow{5}{*}{$\begin{array}{l}\text { The kind of } \\
\text { treatment }\end{array}$} & Biological injection & $66.8 \pm 2.2$ & \multirow{5}{*}{0.37} & $91.8 \pm 5$ & \multirow{5}{*}{0.89} \\
\hline & $\begin{array}{l}\text { Biological injection } \\
\text { and Traditional drug }\end{array}$ & $54 \pm 0$ & & $91 \pm 0$ & \\
\hline & Biological pills & $65.2 \pm 1.5$ & & $89.5 \pm 1.7$ & \\
\hline & Chemical pills & $55.8 \pm 0$ & & $97.4 \pm 0$ & \\
\hline & Traditional drug & $63.3 \pm 2$ & & $88.1 \pm 3$ & \\
\hline
\end{tabular}

Data presented as One-way ANOVA. *statically significant at $p$-value $\leq 0.05$.

\section{Conclusions}

Psoriasis patients showed a significant decrease in the level of IL-36 as compared to its level in the healthy subjects. This decrease may be related to the increase in the severity of the disease. Therefore, it is necessary to conduct additional studies to investigate the levels of this cytokine in the affected skin, its role in the occurrence of the diseases, and the possibility of using it as an anti-psoriasis treatment.

\section{References}

1. Wang, L., Yang, H., Li, N., Wang, W. and Bai, Y. 2015. Acupuncture for psoriasis: protocol for a systematic review. BMJ open, 5(6): e007526.

2. Michalek, I. M., Loring, B. and John, S. M. 2017. A systematic review of worldwide epidemiology of psoriasis. Journal of the European Academy of Dermatology and Venereology, 31(2): 205-212.

3. Trojacka, E., Zaleska, M. and Galus, R. 2015. Influence of exogenous and endogenous factors on the course of psoriasis. Polski merkuriusz lekarski: organ Polskiego Towarzystwa Lekarskiego, 38(225): 169-173.

4. Langley, R. G. 2012. Effective and sustainable biologic treatment of psoriasis: what can we learn from new clinical data?. Journal of the European Academy of Dermatology and Venereology, 26: 21-29.

5. Nestle, F. O., Kaplan, D. H. and Barker, J. 2009. Mechanisms of Disease. Psoriasis. N Engl J Med, (361): 496509.

6. Oka, A., Mabuchi, T., Ozawa, A. and Inoko, H. 2012. Current understanding of human genetics and genetic analysis of psoriasis. The Journal of dermatology, 39(3): 231-241. 
7. Kumar S, McDonnell PC, Lehr R, Tierney L, Tzimas MN. and Griswold DE. 2000. Identification and initial characterization of four novel members of the interleukin-1 family. J Biol Chem. 275: $10308-14$.

8. Dinarello C, Arend W, Sims J, Smith D, Blumberg H. and O'Neill L. 2010. IL-1 family nomenclature. Nat Immunol. 11: 973.

9. Foster, A. M., Baliwag, J., Chen, C. S., Guzman, A. M., Stoll, S. W., Gudjonsson, J. E. and Johnston, A. 2014. IL-36 promotes myeloid cell infiltration, activation, and inflammatory activity in skin. The Journal of Immunology, 192(12): 6053-6061.

10. Carrier Y, Ma H-L, Ramon HE, Napierata L, Small C. and O'Toole M. 2011. Inter-regulation of Th17 cytokines and the IL-36 cytokines in vitro and in vivo: implications in psoriasis pathogenesis. J Invest Dermatol. 131: 2428-37.

11. Saraiva, M. and O'Garra, A. 2010.The regulation of IL-10 production by immune cells .Nat. Rev. Immunol. 10(3): 170-181

12. Moore, K. W., de Waal Malefyt, R., Coffman, R. L. and O'Garra, A. 2001. Interleukin-10 and the interleukin-10 receptor. Annu. Rev. Immunol. 19: 683-765.

1. 13. Al-Robaee, A.A.; Al-Zolibani,A.A.; Al-Shobili, H.A. Kazamel, A. and Settin, A. 2008. IL10 Implications in Psoriasis Int J Health Sci . 2(1): 53-58.

13. Bland, M. 2015. Promiscuous publication. Significance, 12(6): 40-41.

14. Khalaf, H. Y. 2015. Study of Some Immunological Aspects in Patients with Psoriasis in some Baghdad City Hospitals. M.Sc. Thesis. Dept. of Biology, Coll. of Science for Women, Univ. of Baghdad.

15. López-Estebaranz, J. L., Sánchez-Carazo, J. L. and Sulleiro, S. 2016. Effect of a family history of psoriasis and age on comorbidities and quality of life in patients with moderate to severe psoriasis: Results from the ARIZONA study. The Journal of dermatology. 43(4): 395-401.

16. Akçali, C., Guven, E. H., Kirtak, N., Inaloz, H. S., Ozgoztasi, O. and Guvenc, U. 2014. Serum concentrations of interleukin-2 and tumour necrosis factor- $\alpha$ under cyclosporine versus acitretin treatment in plaque-type psoriasis. Journal of International Medical Research 42(5): 1118-1122.

17. 20. Verghese, B., Bhatnagar, S., Tanwar, R. and Bhattacharjee, J. 2011. Serum Cytokine Profile in Psoriasis-A Case-Control Study in a Tertiary Care Hospital from Northern India. Indian Journal of Clinical Biochemistry, 26(4): 373-377.

18. Parisi, R., Symmons, D. P., Griffiths, C. E. and Ashcroft, D. M. 2013. Global epidemiology of psoriasis: a systematic review of incidence and prevalence. Journal of Investigative Dermatology. 133(2): 377-385.

19. El-Moselhy, E. A., Nada, I. S., Khalifa, H. O., Hassan, H. M. and Abd-Alrhman, T. M. 2012. Psoriasis and psoriatic arthritis: characteristics and risk factors among adult patients in Egypt. The Egyptian Journal of Hospital Medicine. 31(758): 1-40.

20. Leovigildo, É. S., David, R. A. R. and Mendes, A. S. 2016. Stress level of people with psoriasis at a public hospital. Anais brasileiros de dermatologia. 91(4): 446-454.

21. Ceovic, R., Mance, M., Bukvic Mokos, Z., Svetec, M., Kostovic, K. and Stulhofer Buzina, D. 2013. Psoriasis: female skin changes in various hormonal stages throughout life-puberty, pregnancy, and menopause. BioMed research international. 1-6.

22. Zeng, J., Luo, S., Huang, Y., and Lu, Q. 2017. Critical role of environmental factors in the pathogenesis of psoriasis. The Journal of dermatology, 44(8): 863-872.

23. 12. Kryston, T. B., Georgiev, A. B., Pissis, P. and Georgakilas, A. G. 2011. Role of oxidative stress and DNA damage in human carcinogenesis. Mutation Research/Fundamental and Molecular Mechanisms of Mutagenesis, 711(1-2): 193-201.

24. 14. Lowes, M. A., Suárez-Fariñas, M. and Krueger, J. G. 2014. Immunology of psoriasis. Annual review of immunology, 32: 227-255.

25. Balato, A., Mattii, M., Caiazzo, G., Raimondo, A., Patruno, C., Balato, N. and Lembo, S. 2016. IL-36r Is Involved in Psoriasis and Allergic Contact Dermatitis. The Journal of investigative dermatology, 136(7): 1520.

26. Sehat, M., Talaei, R., Dadgostar, E., Nikoueinejad, H. and Akbari, H. 2018. Evaluating Serum Levels of IL-33, IL-36, IL-37 and Gene Expression of IL-37 in Patients with Psoriasis Vulgaris. Iranian Journal of Allergy, Asthma and Immunology, 17(2): 179-187. 
27. Johnston, A., Xing, X., Guzman, A. M., Riblett, M., Loyd, C. M., Ward, N. L. and Kang, S. 2011. IL-1F5,-F6,-F8, and-F9: a novel IL-1 family signaling system that is active in psoriasis and promotes keratinocyte antimicrobial peptide expression. The Journal of Immunology, 186(4): 2613-2622.

28. D'erme, A. M., Wilsmann-Theis, D., Wagenpfeil, J., Hölzel, M., Ferring-Schmitt, S., Sternberg, S.,

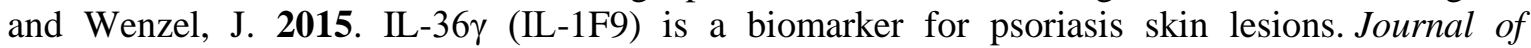
Investigative Dermatology, 135(4): 1025-1032.

29. Ding, L., Wang, X., Hong, X., Lu, L. and Liu, D. 2018. IL-36 cytokines in autoimmunity and inflammatory disease. Oncotarget, 9 (2): 2895.

30. Vigne, S., Palmer, G., Lamacchia, C., Martin, P., Talabot-Ayer, D., Rodriguez, E. and Gabay, C. 2011. IL-36R ligands are potent regulators of dendritic and T cells. Blood. 118(22): 5813-5823.

31. Mutamba, S., Allison, A., Mahida, Y., Barrow, P., and Foster, N. 2012. Expression of IL-1Rrp2 by human myelomonocytic cells is unique to DCs and facilitates DC maturation by IL-1F8 and IL1F9. European journal of immunology. 42(3): 607-617.

32. Onoufriadis, A., Simpson, M. A., Pink, A. E., Di Meglio, P., Smith, C. H., Pullabhatla, V. and Capon, F. 2011. Mutations in IL36RN/IL1F5 are associated with the severe episodic inflammatory skin disease known as generalized pustular psoriasis. The American Journal of Human Genetics. 89(3): 432-437.

33. Marrakchi, S., Guigue, P., Renshaw, B. R., Puel, A., Pei, X. Y., Fraitag, S., and Towne, J. E. 2011. Interleukin-36-receptor antagonist deficiency and generalized pustular psoriasis. New England Journal of Medicine. 365(7): 620-628.

34. Jung, N., Hellmann, M., Hoheisel, R., Lehmann, C., Haase, I., Perniok, A. and Rubbert, A. 2010. An open-label pilot study of the efficacy and safety of anakinra in patients with psoriatic arthritis refractory to or intolerant of methotrexate (MTX). Clinical rheumatology. 29(10): 1169-1173.

35. Setta-Kaffetzi, N., Navarini, A. A., Patel, V. M., Pullabhatla, V., Pink, A. E., Choon, S. E. and Kirby, B. 2013. Rare pathogenic variants in IL36RN underlie a spectrum of psoriasis-associated pustular phenotypes. The Journal of investigative dermatology. 133(5): 1366.

36. Baliwag, J., Barnes, D. H. and Johnston, A. 2015. Cytokines in psoriasis. Cytokine, 73(2): 342350.

37. Borska, L., Andrys, C., Krejsek, J., Hamakova, K., Kremlacek, J., Ettler, K. and Fiala, Z. 2008. Serum levels of the pro-inflammatory cytokine interleukin-12 and the anti-inflammatory cytokine interleukin-10 in patients with psoriasis treated by the Goeckerman regimen. International journal of dermatology, 47(8): 800-805.

38. Deeva, I., Mariani, S., De Luca, C., Pacifico, V., Leoni, L., Raskovic, D. and Pastore, S. 2010. Wide-spectrum profile of inflammatory mediators in the plasma and scales of patients with psoriatic disease. Cytokine, 49(2): 163-170.

39. Borghi, A., Fogli, E., Stignani, M., Melchiorri, L., Altieri, E., Baricordi, O. and Virgili, A. 2008. Soluble human leukocyte antigen-G and interleukin-10 levels in plasma of psoriatic patients: preliminary study on a possible correlation between generalized immune status, treatments and disease. Archives of dermatological research, 300(10): 551-559.

40. Sobhan, M. R., Farshchian, M., Hoseinzadeh, A., Ghasemibasir, H. R. and Solgi, G. 2016. Serum levels of IL-10 and IL-22 cytokines in patients with psoriasis. Iranian Journal of Immunology, 13(4): 317-323.

41. Nickoloff, B. J., Fivenson, D. P., Kunkel, S. L., Strieter, R. M. and Turka, L. A. 1994. Keratinocyte interleukin-10 expression is upregulated in tape-stripped skin, poison ivy dermatitis, and Sezary syndrome, but not in psoriatic plaques. Clinical immunology and immunopathology. 73(1): 63-68.

42. Asadullah, K., Sterry, W., Stephanek, K., Jasulaitis, D., Leupold, M., Audring, H. and Döcke, W. D. 1998. IL-10 is a key cytokine in psoriasis. Proof of principle by IL-10 therapy: a new therapeutic approach. The Journal of clinical investigation. 101(4): 783-794.

43. Lovato, P., Norsgaard, H., Tokura, Y. and Røpke, M. A. 2016. Calcipotriol and betamethasone dipropionate exert additive inhibitory effects on the cytokine expression of inflammatory dendritic cell-Th17 cell axis in psoriasis. Journal of dermatological science, 81(3): 153-164. 